\title{
The Hindu Undivided Family in Independent India's Corporate Governance and Tax Regime
}

Chirashree Das Gupta and Mohit Gupta

\section{OpenEdition}

1 Journals

\section{Electronic version}

URL: http://journals.openedition.org/samaj/4300

DOI: $10.4000 /$ samaj.4300

ISSN: $1960-6060$

Publisher

Association pour la recherche sur l'Asie du Sud (ARAS)

\section{Electronic reference}

Chirashree Das Gupta and Mohit Gupta, « The Hindu Undivided Family in Independent India's Corporate Governance and Tax Regime », South Asia Multidisciplinary Academic Journal [Online], 15 | 2017, Online since 22 March 2017, connection on 21 December 2020. URL : http://journals.openedition.org/samaj/ 4300 ; DOI : https://doi.org/10.4000/samaj.4300

This text was automatically generated on 21 December 2020.

\section{$\oplus \Theta \Theta \Theta$}

This work is licensed under a Creative Commons Attribution-NonCommercial-NoDerivatives 4.0 International License. 


\title{
The Hindu Undivided Family in Independent India's Corporate Governance and Tax Regime
}

\author{
Chirashree Das Gupta and Mohit Gupta
}

\section{Introduction}

1 This paper is an overview of the Hindu Undivided Family (HUF) - a legal entity embedded in tax, corporate governance and state codification of Hindu personal law in India. The HUF found legal recognition in the late $19^{\text {th }}$ century, but it was the Income Tax Act under colonial rule in 1922 that gave it the status of a separate and distinct tax entity. The legal category of the HUF has existed in the tax code since then. This inclusion is based on a much longer history of recognition of customary law by the British colonial state in India. In the interpretation of the colonial state, the HUF represented a joint family that was held together by strong ties of kinship and entailed a variety of joint property relations among the members. There were blurred and porous boundaries between the cultural underpinnings of the family as a social entity and the commercial existence of the family as a trading entity. These porous boundaries were a function of marriage, lineage, patriarchal ties, and trade and business. The colonial interpretation of the entity did not recognize the complex networks which resulted in the family as a business entity being governed by personal laws as against partnership firms being defined by legal contracts (Birla 2008). This had its roots in the colonial legal system which set a clear dividing line between the "public" and the "private." Its "public" side aimed at rendering an individual free of moral relations, and law was meant to shape the individual's relations freely in the market, while its personal side entrenched the denominational status based on caste, religion and family as basis for individual rights (Washbrook 1981).

2 This dual characteristic of the HUF shaped its legal status as a unit of business and taxation. It was recognized as a trading entity/ family firm i.e. an income-generating entity on the production side of the economy. But the arguments against it being taxed 
were based on recognizing cultural ties, customary existence and the notion that the family preceded the firm, and that "family income" was solely for the purpose of maintenance of the unit and fulfilling of customary obligations-i.e. the family was an income-utilizing entity on the consumption side of the economy. This sharp exclusivity of definition inherent in the neoclassical conception of economic activities-with a tight compartmentalization of production and consumption-created for the state the dilemma of deciding what the HUF was at the time the Income Tax Acts of 1860 and 1886 were passed. Both the acts recognized the HUF as a variant of a legal person under the category of "individuals" (Birla 2008). Finally in the debate on the Super Tax Bill of 1917, it was proposed the HUF be recognized as a distinct category for taxation, in order to overcome the problem of the dual characteristics of being a family and a business entity. This interpretation led to the recognition of the HUF as a separate tax entity which was subsequently incorporated into the Income tax Act of 1922 (Newbigin 2013). It is this dual existence of the HUF as both a family and a firm that makes it distinctive from all other institutional categories, as we shall see in the next two sections.

However, it was in the first decade after independence that the HUF was legally consecrated (as originating in state code through the codification of Hindu customary and personal law) and then integrated into the Indian corporate governance and taxation system. Thus the HUF's consecration in state code is the major departure in its status after independence as compared to the colonial period.

The historical literature on the evolution of institutions of Indian business in the colonial era and the first three decades after independence has focused on the political economy of colonialism, caste, community and the specificities of the mercantile character of the "business-house" structure, thus recognizing the business house (as an institution consisting of interlocked corporate entities and not discrete firms and companies) as the unit of organization of capital and business (Bagchi 1972; Markovits 1985; Tripathi 1990; Tyabji 2000). In sharp contrast in the last two decades, the dominant literature on the post-independence period is based on an envisioning of Indian business as a plethora of independent firms whose relationships with one another are based on industrial clusterformation. These firms are buyers and sellers in and across industries and disparate entities, which have economic linkages mediated by the market as opposed to institutional linkages through organizational inter-locks (De Beule and Narayanan 2016). In India, the organization of the "business house" was legally sanctioned through multiple pieces of legislations spanning corporate and tax laws and it forms the object of studies in the literature on "corporate governance" (Sarkar and Sarkar 2012). But the relationship between the discrete legal units recognized as private income- or wealthgenerating and accumulating entities (individuals, partnership firms, public and private limited companies, trusts and societies and the HUF) are not the subject of critical examination. Both in law and the study of law, the unit of analysis assumes all units that comprise a business group to be distinct, separate and mutually exclusive wealth-and income-generating entities.

5 A third set of sociological literature (Singer 1968; Owens 1971) examined the family and business interface from a socio-cultural perspective, but did not examine the legal embedding of the family-firm/business-house inter-locks. This lacuna is significant because, just when this literature was being generated, the Hazari report in 1967 officially identified the "business group" consisting of inter-locking firms and companies as the basic institutional unit of organization of Indian big capital. This was opposed to the 
dominant macroeconomic construction that followed later of "firms" and "households/ family" as disparate and mutually exclusive units of analysis. In Hazari's analysis the group consisted of a number of related and unrelated activities of a plethora of firms and companies, controlled by a single central decision-making authority and thereby functioning as a coordinated organization. The report showed that besides a high degree of product concentration, big capital in India was dominated by a few representative units of capital organization (through interlocked firms) in most areas of industry and trade in the form of the "business group" (Hazari 1967). The key groups of business, both old and new, maintained both ownership and control over capital flows and decision making through the modalities of the institutional structure of the family run business house (Das Gupta 2010, 2016). This was the understanding of the structure of monopoly capital in India as opposed to monopoly conceptualized as product and market concentration in the mainstream economic literature. In this paper, this conceptualization of the monopoly of family-run business houses, in the institutional organization of capital-accumulation structures and processes in India, follows from the analysis of monopoly structures and process in terms of ownership and control over capital flows and decision making in the entity of the family-run business house.

6 More recently, the study of the legal institution of the "family" has fallen in the ambit of specialized readings of "personal laws" with respect to the relationship between religious code and property rights (Agnes 1990, 2011; Parashar 1992). But it does not examine the family/firm interface. While the entity of the "business group" has found its conceptual space in institutional economics and the larger social science literature, the familial basis of ownership and control of corporate structures remains a grossly understudied area. The relationship between the two and the regimes of accumulation in independent India has been largely unexplored in the otherwise growing corpus of business studies and business-management literature on the relation between the family-owned business group, "corporate governance" and public policy in not only India, but also the USA, Canada, Europe, Hong Kong, Taiwan, Japan, South Korea, China and Pakistan (Gulzar and Wang 2010). The peculiar form of the HUF as a distinct form of property holding for the purpose of corporate governance and taxation has only recently been recognized in the literature (Dewan 2009; Das Gupta 2013; Das Gupta 2016).

7 The legal provisions of "corporate governance" structures have facilitated the optimum mix of various forms of registered companies such as partnerships, private limited companies, unregistered and registered public limited companies under the umbrella group through interlocking share-holdings. These interlockings were made possible through the legal provisions of the Indian Partnerships Act of 1932 and the Companies Act of 1956. This not only was a mode of risk spreading, but also provided legal avenues to escape the Monopolies and Restrictive Trade Practices after 1973, until it was repealed in 1991. It was also important for labor deployment and control with employers, often ensuring that each company had less than seven employees and pre-empting any possibility of trade-union formation under the stipulations of the Trade Union Act of 1926 (Das Gupta 2016).

8 In corporate law and personal law-the two spaces it inhabits-the HUF has been largely regarded as incongruent with "modern" corporate governance and taxation structures (Sachdeva 1987). It is often referred to as a remnant from an archaic time that does not serve any purpose in contemporary modes of capital accumulation. The women's movement in India, which has had the closest critical engagement with this structure has 
often associated it with feudal structures of land and property holdings. Its implications for capital accumulation in the "modern" sectors have not been studied at all. This paper is an attempt to arrive at a comprehensive delineation of the role of the HUF in the corporate governance and taxation regime in independent India.

Interlocked firms and families are the legal structure in which capital accumulation is institutionally embedded in India. It may also be noted that the first level of the firm/ family interlock is germane to capitalism universally, i.e. individual members of families own and control shares. But in India, the HUF interlock with firms is unique and specific in not only maintaining the family's control over the family business, but also driving a range of activities related to capital accumulation which do not get captured in the taxation structure. Moreover, this privilege as a legal entity is only given to Hindus as defined in the state's codification of Hindu personal and family law-a Hindu is anyone who is not a Muslim, Parsi, Christian or Jew.

10 The rest of the paper is divided into three sections. Section I elucidates the process through which the HUF was institutionally embedded into the state's codification of Hindu personal and family law. Section II analyzes the institutional embedding of the HUF in corporate governance structures. Section III dwells on installation and use of the HUF in tax structures and the role it plays as a vital institution in tax avoidance processes. The three sections together show the critical role the HUF plays in the circuits of capital accumulation in India.

\section{Installation of the HUF through the Hindu Code}

11 The codification of Hindu Personal laws continued for more than nine years from 1947 to 1956 as part of the exercise of nation-building. The original draft of the bill by Dr. B R Ambedkar (who resigned from the Union Cabinet in protest after agreeing to many of the changes that were inserted at various stages of the debate) was watered down through political compromise and was finally broken down into four separate acts on marriage, guardianship, succession and adoption which were passed in Parliament between 1955 and 1956. Big capitalists played a significant part in the process through which Hindu personal law became state law in India in 1956 (Das Gupta 2013; Das Gupta 2016).

The first step towards the legal sanctification of the HUF as the institutional basis for organization of the business group was achieved through the codification of Hindu personal laws. First, the Hindu code (adopted as state code) defined a Hindu as anyone who was not a Muslim, Christian, Parsi or Jew and thus by default included followers of other institutionalized religions like Buddhism, Jainism and Sikhism in the Hindu category, along with a range of theistic practices outside the domain of organized religion like those of adivasis. Thus the onus was placed on the individual to prove if necessary that she/he is not a Hindu (Das Gupta 2016).

The same code recognized both Dayabhaga and Mitakshara-the two forms of customary caste-Hindu property holdings (a compromise over the original draft which had proposed to do away with customary laws in defining hereditary rights to property)-and marriage only between two Hindus (according to hetero-normative customary law based on caste rules and practices on both endogamy and exogamy) as falling within the ambit of the code. Adoption and succession were to be defined in jurisprudence by the state's Hindu code, institutionalizing male lineage of descent as the "natural" inheritors of property 
and the expropriation of any right to property of children born outside marriage. Thus, Hindu personal law became state law, embedding the definition of the Hindu Undivided Family.

14 The patriarchal basis of the property-rights structure was institutionalized in the organization of wealth and property. Women were denied an equal share in any property. Specifically, they were denied any property right to land on the feeble excuse of preventing the "fragmentation of land." Thus with the aid of two definitions, that of a Hindu and that of the HUF, religion, caste and patriarchy were installed as the institutional basis of determining property rights. The modification of the right to property as a statutory right guaranteed by the Constitution, in favor of Hindu males through the creation of the legal entity of the HUF, was the most significant intervention of the first post-independence decade (Das Gupta 2013).

The impact of this institutional arrangement became evident as soon as the codification was completed in 1956, with a sudden spurt in the proliferation of HUFs. The annual growth of the number of HUFs jumped to $38 \%$ in 1957-58 when the growth of all tax entities amounted to $16 \%$. The average annual growth rate of HUF accounts between 1954-55 and 1965-66 was $9 \%$ while all tax entities grew at close to $12 \%$. In this period, HUFs on average accounted for $6 \%$ to $8 \%$ of tax assessees and $5 \%$ to $8 \%$ of the total income assessed (Statistical Abstract of India, All India Income Tax Statistics, Various Years).

The codification of Hindu personal laws preserved the patriarchal rules of limiting women's rights to inherit property and assigned the "karta"-the eldest patriarch of the family-legal powers to represent and make decisions to structure the holding of property (Sachdeva 1987). In case law (based on the Hindu code adopted by the state), an HUF consists of all persons lineally descended from a common ancestor and includes their wives and unmarried daughters, while a Hindu co-parcenary is a much narrower body including only those persons who acquire by birth an interest in the joint or co-parcenary property. Before the 2005 amendment, the Hindu Succession Act made a provision for a Hindu Undivided Family in order to ensure that property would remain with the male line of descent. As a co-parcenary, a son got a share equal to that of his father; a daughter got only a share in her father's share. She could not reside in the family home unless she was single or divorced, and could not claim her share of property as long as the men of the family continued to live in it. Further, a woman's right to agricultural property was still denied to "prevent fragmentation of landholdings" (Das Gupta 2016). Contrary to assertions that the 2005 amendment "established a gender-equal basis of land and agricultural property" (Kelkar 2014), it gave only daughters the right to be co-parcenaries in HUFs under Mitakshara rules, and excluded wives and daughters-in-law (Singh 2005). Moreover, the status of the "karta" and the HUF as a form of property holding in a body incorporate were not affected by this amendment. The status of the karta was preserved in its implication for inheritance rights as well as the HUF as a tax entity (which is elaborated in the last section).

17 It created the formal legal space for any Hindu male to break away from the "joint family" and start a new "Hindu Undivided Family" as karta as long as he was married. Even as families went nuclear, the "HUF" could be perpetuated as a legal entity, as each nuclear family marked the beginning of a new "HUF" because a Hindu male can be a " karta" for more than one HUF accounts. So every time a joint property is partitioned or a joint family breaks up into nuclear units, it gives rise to a new "Undivided" family. Thus 
the expansion of the HUF through male lineage is the only pre-condition to the formation of new HUFs.

\section{The HUF in Corporate Governance}

18 In 1956, the Companies Act recognized the HUF as a legal entity in independent India which could be part of ownership and control structures of corporate entities, i.e. private and public limited companies. The Indian Partnership Act of 1932 had already given similar recognition to the HUF in holding structures of partnership firms. The interlocking of the HUF with corporate governance structures is mediated by the role of the karta in his dual role-as an individual legal person and as karta of the HUF. For instance, a HUF cannot enter into a partnership with other persons, as it is not a legal person, but the karta of a HUF can (Sachdeva 1987). Similarly the karta and the other members of a HUF are entitled to receive a salary and compensation as a legal person. Also an HUF can be a proprietor of one or more business firms by maintaining names separate to the HUF as a business entity. Further the HUF can own different kinds of assets including factories, land, property and trades. This legal interlock of the HUF with companies and firms is central to the holding asset structures of Hindu family-owned business groups in India. Both "old" and "new" capitalist business houses of Hindu origin use the provision of HUF to consolidate family holdings and ensure the control of capital within the family through transactions between the HUF and individuals within the HUF, these individuals occupying key positions in the share-holding and managerial patterns of the companies within the fold of the business house, through interlocking directorships and share-holding.

One of the most important features of the "old" regime of accumulation was the mercantile basis of Indian family-owned business groups. The few explanations for this phenomenon have been rooted in the realm of either "behavioralism" or "culturalism." While on the other hand, the studies of "new" capitalists-which have been emphasizing the diversification of the regimes of accumulation between 1956 and 1980 (e.g. Damodaran 2008)-have missed out on the one unchanging feature of the "business group," which is its ability to retain control over diverse ventures with very little investment of family wealth.

The distinction between ownership and control gets blurred in the complexity of holding structures, through the maze of inter-corporate holdings and interlocking directorships (Mazumdar 2006). The interlocking of the HUF into overlapping directorships and intercorporate holdings provides yet another layer for ensuring family control over corporate governance structures, apart from providing an avenue for concessions on wealth and income. In the absence of any official account of such interlocked holdings, case law is one avenue through which this relationship can be studied. Our analysis of twenty five landmark HUF related cases involving some of the top business houses in India shows the following uses of the HUF:

1. To keep property within the Hindu family (based on the male line of descent) using the definition of the Hindu as adopted in the Acts based on the Hindu Code.

2. Splitting of income between individuals and HUFs for the purpose of tax avoidance.

3. To evade large amount of taxes by entering into complex transaction between HUF and Group Companies with same person as karta and chairman respectively.

4. To gain benefits of tax exemptions in capital gains. 
5. Holding land of enormous value in HUFs claiming to be received as dowry by ancestors

6. Interlocking of funds and assets between HUFs and group companies

7. To make a profit from speculation through sale and purchase of shares of group companies by the HUF.

8. Multiple HUFs within the same family with overlapping kartas and members and then multiple dealings of a single property by these different HUF eg same land pledged for different purposes by repeated transfers between HUF holders.

The case law analysis summarized above is indicative rather than exhaustive. However, it does bring out the peculiar provisions of the HUF that "Hindu" business houses have used in different spatial and temporal contexts to perpetuate capital accumulation. Needless to say, no such provision was available to business houses held by Muslims or Christians, Parsis or Jews. While the interlocking characteristics of family-owned trusts are used by business groups from all religions, the HUF is a favor exclusively for Hindus as defined by the Hindu code. There is no equivalent structure or provision for business groups belonging to other religions.

The other method through which the HUF can be studied is through survey. Using snowball sampling techniques, we carried out a survey of financial statements and institutional interlocks of 150 business groups in two phases between 2003 and 2005 and between 2008 and 2011. This survey consisted of 150 business families, the study of the financial statements of the last ten years of 7,500 firms affiliated to these 150 business families. This survey also involved 1,000 extensive interviews with members of business families, and managers and employees in family-controlled firms. These interviews were based on written and/or oral consent based on the condition that no identities would be revealed in the study.

The survey (spread over Kolkata, Mumbai, Delhi and Hyderabad) reveals judicious use of provisions in personal and corporate governance laws, with each group consisting of some or all of the legal forms of partnership firms, private limited companies, unlisted public limited companies and listed public limited companies (using the provisions of the 1932 Partnerships Act and of the 1956 Companies Act). The holding structures are comprised of individually-owned stocks, along with stocks held by Hindu Undivided Family accounts (except for the two business groups of "non-Hindu" origin in our Survey), ${ }^{1}$ and a number of "group" companies spread across the four forms of business entities stated above. In 35.3 percent of the groups surveyed, stocks in group companies are not held by HUFs in publicly-listed companies, but are held in the "private limited" companies. However, the kartas of the HUF or other HUF members hold stocks in the publicly listed companies in 61.3 percent of the groups surveyed. Thus the payouts to the HUF as well as to the individual who is part of an HUF is simultaneously maintained. At the same time, the HUF can hold other property, e.g. houses, cash, gold, share certificates, fixed deposits which would not be considered in the asset accounting of the business group. The income and wealth holdings in the HUF do not get counted in the business group's ownership and control of assets (Das Gupta 2016).

Table 2.1: Survey Summary

Number of business families surveyed 150

South Asia Multidisciplinary Academic Journal, 15 | 2017 


\begin{tabular}{|l|l|}
\hline $\begin{array}{l}\text { Number of firms affiliated to business groups which were analyzed for institutional } \\
\text { interlocks }\end{array}$ & 7,500 \\
\hline Average number of companies/firms in a family-owned/controlled business group & 47 \\
\hline Average number of HUFs found to be interlocked in each business group & 9 \\
\hline $\begin{array}{l}\text { Average number of trusts/registered societies found to be interlocked with each } \\
\text { business group }\end{array}$ & 4 \\
\hline Number of detailed case studies of family owned business groups & 25 \\
\hline Number of members of business families interviewed as part of case studies & 300 \\
\hline Number of managers of firms interviewed as part of case studies & 300 \\
\hline Number of employees who were not managers interviewed as part of case studies & 200 \\
\hline
\end{tabular}

Thus, on an average, for every five firms controlled by a family-owned business group, there is one HUF to play the pivotal role of legal facilitation of family control over the holding structures of family-owned business groups.

\section{Family Control over the Circuits of Capital within the Business Group}

The provision of the HUF is used to consolidate family holdings and ensure the control of capital within the family through transactions between the HUF and individuals within the HUF who hold key positions in the share-holding and managerial patterns of the companies within the fold of the business house, through interlocking directorships and share-holding.

To illustrate the modalities of family control over the circuits of capital within the business group, we present a case study from our survey of a family-owned business group based in Mumbai:

27 Patriarch A from business family $\mathrm{X}$ is married to $\mathrm{B}$ from business family $\mathrm{Y}$. They have two sons $C$ and $D$ and one daughter E. $C$ and D have a son each named $M$ and N. Daughter $E$ is married to $\mathrm{F}$ into business family $\mathrm{Z}$. Sons $\mathrm{C}$ and $\mathrm{D}$ are married to $\mathrm{G}$ and $\mathrm{H}$ from business families $\mathrm{V}$ and $\mathrm{W}$.

The HUFs created from these alliances in Family $\mathrm{X}$ are:

1. HUF1 (A -karta, C and D coparcenaries, B member):

2. HUF2 (C - karta, G member)

3. HUF3 (D- karta, H member)

4. HUF 4 (A-karta, C - coparcenary, B and G member)

5. HUF 5 (A-karta, D - coparcenary, B and H member)

6. HUF 6 ( $\mathrm{C}-$ karta, M coparcenery (minor with $\mathrm{C}$ as guardian)

7. HUF 7 (D - karta, N coparcenary (minor with D as guardian) 
Similar HUFs exist in families V, W and Z. Family X has two flagship companies-ABC Ltd and DEF Ltd. Five percent of the shares in ABC Ltd are held by A, B and C. Another three percent shares are owned between HUFs 1, 2 and 4. Similarly, six percent of the shares in DEF Ltd are held by A and D. Another two percent is held by HUFs 1, 3 and 5. Eight other group companies together hold a ten percent share of ABC Ltd. Seven different group companies hold an eleven percent share of DEF Ltd. There are two other subsidiary/ holding companies in the group. These hold shares in nine other group companies. HUFs 6 and 7 hold a two percent share in ten of the group companies. Two group companies along with A, B, C, D, E, F, G, H hold shares in three trusts named after A's grandfather, father and mother respectively. These trusts own shares in six group companies. The HUFs belonging to families $\mathrm{V}, \mathrm{Y}, \mathrm{W}$ have shares in six group companies. The daughter, son-in-law and the daughters-in-law (E, F, G and H) own shares as individuals in six corporate entities in which three are partnerships and three are companies. Thus individuals, HUFS, firms/companies and trusts form multiple levels of overlapping interlocks to control 26 firms/companies and two trusts, even though each of these entities is governed by different corporate governance laws as we have shown earlier.

A, the patriarch is a director in six companies, The sons C, D and son-in-law F in four each, the daughter $\mathrm{E}$ in two, three members each from families $\mathrm{V}, \mathrm{W}$ and $\mathrm{Y}$ in two each. All the women in the family are involved in active management of the trusts in a position of executive authority. Had there been no HUF provision, individual family members would need to own a much larger proportion of the shares in order to exert family control over the constituent firms/companies in the business group.

31 This business group owned two large and six medium sized factories and two small scale enterprises spread over four states in India. Out of these, two were owned by public limited companies, four were owned by private limited companies, two by HUFs and two by partnerships. These factories were integrated into the global textiles value chain at different levels, with a production range of intermediate goods. Fifteen other corporate entities in the group were shown to be invested in hotels, trading, property dealing and leasing, and entertainment (a digital studio). One partnership firm was invested in financial services while the trusts ran for-profit schools along with temples, an old-age home and an ecological park. However, on an average, sixteen out of the twenty-six corporate entities reported losses in the previous four years. With asset and income transfers within group companies and HUFs (through related party transactions which are captured in the financial statements), profit and loss accounting was spread across business groups to declare the minimum level of profits to avoid taxation in nine consecutive years from 2002-03 to 2010-11.

The HUF also exists legally in tax law independent of these interlocked entities. For example, the land for three of the factories is owned by three different HUFs of family $\mathrm{X}$ and is shown in financial statements to have been leased to the company owning the factory.

33 A similar case study of the largest business group in India by Naz (2016), shows that around 64 out of 88 interlocked group companies, reported a loss in two consecutive years in 2013 and 2014. It must be noted here that such related party transactions must by law be approved by the Board of the company. Given the interlock between family members on the board, such transactions are facilitated by the legal sanction of the corporate governance structure interlocked with the family (Naz 2016). 

significant aspects of the firm/family interlock. All four women had been married through alliances brokered by the family. Two of the four women were married into families whose ethnicity was different from their own. However, all four alliances were based on caste rules of endogamy/exogamy along with considerations of class status. All four women narrated how they were part of fundraising (own capital) for multiple business groups spanning the families inter-connected through marriage. They called these "deposits," which were made by women either informally in cash or formally through personal cheques from their own bank accounts to one or another HUF. These would then be channeled through the HUF into various related party transactions to fund the purchase of land, investment in machinery or stocks and bonds, all of which then are used in the accumulation activities of group companies. These deposits return, completing the circuit of capital at higher than the original value through the same circuitous routes as family income, very much in keeping with Marx's original exposition of M-M' i.e. the social relation of capital as money begetting more money than its original value (Marx 1887). As the monetary transactions are between the HUF and the individual, these never show up in the accounts books of the corporate entities. Thus the legal separation of the individual, the HUF of which the individual is a member, and the company in which the HUF and the individual exert ownership and control, create the formal legal structure in which the informality of exchange between members of the family to generate and accumulate capital is embedded.

Within the structure of the family-owned business group, the importance of Hindu Undivided Family assets have not declined, even as many of the business groups in question have forged relationships based on technological dependence and spates of mergers with and acquisitions of both indigenous and foreign companies. It has only meant that the wealth holdings in the HUF cannot be used for controlling stakes in the merged foreign entity, as opposed to the wealth held through "corporate governance" structures. But the interlocking of HUFs in "Hindu" corporate entities still makes it a vehicle for family control over all the operations and stakes of the "corporate" business group and continuous rearrangement of liabilities and tax obligations between individuals and the HUFs. In absolute terms, the number of HUF assessees almost doubled between 1991 and 2000 from around two hundred thousand to four hundred thousand. The number of HUFs assessed for income tax increased by 47\% in 1997-98 as compared to the previous year and registered double-digit annual growth rates in eight out of twenty years between 1990-91 and 2009-10. As per the latest income tax data released by the Central Board of Direct Taxes in 2016 there were 9,40,061 effective HUF assessees in 201415 that had appeared in the income tax statistics while their number stood at 4,47,820 in 1999-200, the year after which disaggregated data was not provided; disaggregated data was not provided beyond this date. So even as per official statistics the number of HUFs has almost doubled within a decade and increased almost four-fold since 1991.

Table 2.2 compares the disaggregated growth rates of HUFs with that of companies and firms (i.e. partnerships and sole-proprietorships) added together. In seven out of thirteen years for which comparable data is available, the number of HUFs has grown faster than that of firms. In the three years during which the number of companies and firms has shown an annual decline, the HUF has also shown a decline. Thus the growth of the HUF is similar to that of firms and companies and distinctly different from individual tax assessees whose growth rate has exceeded $100 \%$ in all the thirteen years for which we 
have comparable data (Table 2.2). This feature has to do with the "business" entity of the HUF, which is further elaborated later in this section.

Table 2.2: Annual Growth Rates of HUFs Compared to Companies and Firms after 1991

\begin{tabular}{|c|c|c|c|}
\hline Year & $\begin{array}{l}\text { Annual Growth of } \\
\text { HUFs (\%) }\end{array}$ & $\begin{array}{l}\text { Annual Growth of Firms and } \\
\text { Companies (\%) }\end{array}$ & $\begin{array}{l}\text { Annual Growth of } \\
\text { Individuals (\%) }\end{array}$ \\
\hline 1990-91 & 10.82 & 15.57 & 114.34 \\
\hline 1991-92 & -8.93 & -5.70 & 105.99 \\
\hline 1992-93 & 11.31 & 1.13 & 115.69 \\
\hline 1993-94 & 7.98 & 4.54 & 112.76 \\
\hline 1994-95 & 24.79 & 28.05 & 137.81 \\
\hline 1995-96 & -3.62 & -2.22 & 101.03 \\
\hline 1996-97 & -6.31 & -7.60 & 108.41 \\
\hline 1997-98 & 47.13 & 26.61 & 122.99 \\
\hline 1998-99 & 0.06 & 3.72 & 118.61 \\
\hline $\begin{array}{l}1999- \\
2000\end{array}$ & 10.53 & 6.51 & 132.70 \\
\hline $2012-13$ & 87.59 & 18.14 & 203.09 \\
\hline 2013-14 & 6.86 & 4.77 & 116.11 \\
\hline 2014-15 & 4.72 & 7.43 & 108.72 \\
\hline
\end{tabular}

Source: Authors' calculations based on data released by Central Board of Direct Taxes, Various Years

Socially, nuclearization of families is directly combined with proliferation of HUF accounts among middle-class, double-income, upwardly-mobile, caste-Hindu India. One of the features associated with the neoliberal era has been that family-owned business groups have been transforming themselves into multi-nationals without an increase in their total corporate liability through vertical and horizontal integration. This is possible because the laws in India have been suitably altered to facilitate such transformation of firms in the period of contemporary globalization by the reduction of the compulsory share of Indian partners in a transnational venture, the introduction of limited liability partnerships, the dismantling of the MRTP and FERA Acts, and amendments in the National Patent Act to make it amenable to the WTO regime of product patents (Das Gupta 2010). However, the laws relating to holding structures of companies remain flexible enough to accommodate the requisites of change in corporate governance but are unchanging in their function of providing the legitimate basis of family-owned business groups spanning the entire domain of ownership, control and individual- and family- 
based appropriation of profit in favor of the "Hindu," defined as anyone who is not a Muslim, Christian, Parsi or Jew (Das Gupta 2016).

In the post liberalization period, it also provides yet another channel of "tax-saving" on income and wealth for not only upwardly-mobile "Hindu" families in India, but also for Hindu Non Resident Indians (NRI). The 1961 Income Tax Act specifies the residency status of citizens and entities into three broad categories-resident, nonresident and not ordinarily resident (NOR). This trilateral categorization also existed in the colonial Income Tax Act of 1922. The 1939 amendment to the 1922 Income Tax Act allowed "NOR" status for individuals only. For the HUF and other assessees, the status was restricted to ordinary residents. It was only with the 1961 Income Tax Act that NOR status, which was earlier available only to individuals, was extended to the HUF in Section 6(6)(b), which provides that a HUF can be NOR if the manager is an NRI and has stayed outside India in nine out of ten previous years or has remained in the country for less than 729 days in past 7 years. This legally allows business families to register a HUF in India, conduct their business abroad for years and establish the presence of the manager of the HUF in the country for the minimum stipulated period to enjoy the benefits of the HUF (for instance if a father and his two sons have a HUF, the father can return to India occasionally while his sons continue to do business abroad). The residential status of an individual has to be established by physical presence in the country over a certain time. But for the other corporate governance structures having a separate legal existence, the residential status was extended under the Income Tax Act on the basis of establishing management and control in the country, a caveat which by definition brings in an element of ambiguity. The HUF was treated on par with corporate entities on this point and the provision that was meant for firms also applied to the HUF. This was in continuity with the 1922 colonial Income Tax Act. Subsequently, Section 6(2) of the 1961 Income Tax Act provided that a HUF is recognized as a resident in India in every case, except when its control and management is situated wholly outside India. This provision goes a step further than the earlier provision where the manager or karta has to establish presence for a brief period. This allows the karta to reside outside the country. HUF benefits can be taken advantage of as long as there is an official devolution of the powers of control and management to the other members of the family who stay in the country.

Thus the interlock of the caste-Hindu patriarchal family with corporate governance institutions is formally embedded in law in India. It is the materiality of capital that forges the social entity of the family-owned business group, which is formally, legally embedded in the seamless interlock of the firm and the family. This spans state codification of Hindu family law, corporate governance laws and taxation laws. Moreover, this unique legal family/firm interlock is not available to Muslims, Christians, Parsis or Jews and hence constitutes a perverse legal privilege for the Hindu family. The casteHindu patriarchal family bound by son preference is an imperative of the social reproduction of institutional accumulation structures in India. Trust and informality of kinship and familial relationships are very much "within the law." It is capital in its material social role, at work in the circuit of financial and capital flows, that drives the network of institutions that constitute the "family-owned business group" in India, which is legally and formally undergirded by caste, patriarchy and religion. 


\section{Installation and Uses of the HUF in Tax Structures}

40 The recognition of the Hindu Undivided Family as a legal tax entity, separate and distinct from individuals and corporates (which were firms defined under the Companies Act and the Partnership Act), was the final step in defining the legal entity of the HUF. While all other corporate bodies recognized in corporate and individual income tax laws are defined on the basis of company law, the HUF as a legal entity in Indian tax law is defined on the basis of Hindu personal law. After defining the HUF through the codification of personal laws in 1955-56, the state then took the next step to perpetuate the "Hindu Undivided Family" (HUF) as an entity recognized by the 1957 Wealth Tax Act and Section 2 of the 1961 Income Tax Act, as a distinct unit of taxation, with the grant of tax avoidance facilities on "family income," with higher exemptions and lower tax rates as compared to other categories of assessees. Under the income and wealth tax laws in India, an HUF is assessed for tax as a distinct unit of assessment and its interlocking relationship with other income- and wealth-generating entities like companies and firms is not taken into account in the calculation of tax liability.

41 Though the HUF was recognized in colonial income-tax laws earlier (discussed in the introduction), in 1936, the Ayers Committee mentioned the need for recognition of the HUF but did warn of substantive revenue loss if any special exemptions were granted. It is significant that a decade later such a consideration did not prevail over the committees which were constituted to make recommendations on direct taxation after independence. Some of these committees justified the preferential tax treatment to the HUF and further recommended higher tax exemptions than other assessees as an incentive for remaining a joint unit. ${ }^{2}$ Others either did not mention or failed to provide a solution, citing reasons like the administrative burden involved, except for two significant exceptions-the Wanchoo Committee and the K. N. Raj Committee. ${ }^{3}$ Hence the tax provisions served the objective of preserving the interest of the capital-owning class of caste-Hindu origin by offering a plethora of special concessions under the aegis of the HUF. The Wanchoo Committee report was scathing in its assessment of the purpose of the HUF. It held that: "We feel convinced that the Hindu Undivided Family as a unit of assessment is retained in most cases only when it enables the person concerned to reduce their tax liability and that in other cases, it is promptly partitioned without considerations of sentiments coming in the way."

42 A member of a HUF is not taxable at for any sum which s/he receives as a HUF member out of the income of the family, even though the family may not have paid any tax on its own income. So the privilege cannot be ascertained by how much tax a HUF pays, but by how much of its income is not taxed at all by virtue of being declared as "family income." Moreover, an individual can organize her/his wealth across multiple HUFs and thus reduce her/his effective tax liability.

\section{Use of the HUF for Tax Avoidance}

43 There is a distinction between statutory and effective taxation rates. The statutory rates of taxes are defined by the government for various categories of assessees. Statutory income tax rates are defined by the government annually as part of the annual budget announcements through tax slabs based on income declared. These tax slabs are defined 
in terms of a certain percentage of income, which increases with increasing intervals of income threshold. There is a difference between the statutory rates, which are announced every year by modification of the Finance Act, and what finally translates into the actual payments as taxes by income tax payers. These actual payments as percentage of declared income are called the effective tax rates (Bandyopadhyay 2012; Rao 2015). Hence there is a fine distinction made between effective and statutory tax rates (where the statutory rates are the ones prescribed by law and the effective tax rates are the realized average tax rates). For instance in a comparison of the Transitional economies with an advanced one like the EU, the ratio between these two tax forms (effective and statutory) for direct and indirect taxes was taken as basis for analyzing the tax administration and policy prescriptions (Schaffer and Turley 2001). Therefore algebraically, the effective rate of taxes which can be described as the actual tax payable by an assessee as a proportion of the income/profit before taxes can be assessed. The very construction of effective tax rates then makes them lower as opposed to the statutory rates prescribed by the government if the level of exemptions for tax assessees is high. It is also important to mention here that the percentage of effective tax rates gets lower on account of exemptions, subsidies and rebates, which can be both implicit and explicit. Exemptions are granted for investments in pension funds, insurance policies, government bonds, housing loans etc. The taxable units circumvent the mandatory/statutory payments by deploying various ways to lower effective tax rates (ETR) using exemptions. However the HUF provides a further mechanism for tax avoidance for Hindu business families. Table 3.1 presents statutory tax rates reduced to a scale of Rs 100 as equivalent to Rs $10,00,000$.

Table 3.1: Statutory Tax Rates in India: 2015-16

\begin{tabular}{|c|c|c|c|}
\hline Income Tax Slab & Income Tax Rate & $\begin{array}{l}\text { Income Reduced to } \\
\text { Unit of Rs } 100\end{array}$ & $\begin{array}{l}\text { Actual Tax to be paid } \\
\text { on Income }\end{array}$ \\
\hline $\begin{array}{l}\text { Income up to Rs. } \\
2,50,000\end{array}$ & Nil & 25 & 0 \\
\hline $\begin{array}{l}\text { Income between Rs. } \\
2,50,001 \text { - Rs. } 500,000\end{array}$ & $\begin{array}{l}10 \% \text { of } \quad \text { Income } \\
\text { exceeding Rs. } 2,50,000\end{array}$ & $25-50$ & $<$ or $=2.5$ \\
\hline $\begin{array}{l}\text { Income between Rs. } \\
500,001 \text { - Rs. } 10,00,000\end{array}$ & $\begin{array}{l}20 \% \text { of } \quad \text { Income } \\
\text { exceeding Rs. 5,00,000 }\end{array}$ & $50-100$ & $>2.5$ and $<$ or $=10$ \\
\hline $\begin{array}{l}\text { Income above Rs. } \\
10,00,000\end{array}$ & $\begin{array}{lr}30 \% \text { of } & \text { Income } \\
\text { exceeding } & \text { Rs. } \\
10,00,000 & \end{array}$ & $>100$ & $\begin{array}{l}\text { As per actual income } \\
\text { exceeding Rs } 100\end{array}$ \\
\hline
\end{tabular}

Note: Rates are for 2015-16 as per the 2016 Finance Act

Let us start with a Hindu business family that consists of Patriarch A, his wife B, two sons $C$ and D and daughter E. Let us say the family controls a firm called Patriarch \& Sons (P\&S) in which the father is the owner/manager and has an annual income of Rs 100 from this firm. If there is no HUF provision, A will pay no tax on the first Rs 25 of the annual 
income, Rs 2.5 for the next Rs 25 and Rs 10 for the next Rs 50 that he earns. So on his total income of Rs 100, he would pay Rs 12.5 . So his ETR would be $12.5 \%$.

However, because there is the legal HUF provision, A will form an HUF with himself as karta, his sons and daughter $-\mathrm{C}, \mathrm{D}$ and $\mathrm{E}-$ as co-parcenaries and his wife B as member. Let us call this HUF 1. Using firm/family interlocks (described in Section II), he will report Rs 50 as income of the HUF and Rs 50 as his own individual income. Since the tax law does not recognize the relationship between the individual and the HUF, these separate entities each will be taxed as follows. The HUF will pay no tax on the first Rs 25 and will pay Rs 2.5 on the second Rs 25, i.e. the HUF tax liability for an income of Rs 50 will be Rs 2.5 , which is an effective tax rate of $5 \%$. The same rates apply to individuals. So A as individual on his reported income of Rs 50 will also pay Rs 2.5 as income tax which is an ETR of $5 \%$. Thus by the combination of one individual, one firm and one HUF, effective income tax liability can be brought down from $12.5 \%$ to $5 \%$.

Let us say A's income from P\&S increases to Rs 300 in the next year. His total tax liability would be none for the first Rs 25, Rs 2.5 for the next Rs 25, Rs. 10 for the next Rs 50 and Rs 60 for the Rs 200 rest of his income. This would be a total tax liability of Rs 72.5 on an individual income of Rs 300 which implies an effective tax rate of $24.2 \%$. It is at this stage that two more HUFs would be formed if and only if the two sons are married:

- HUF1 (Described earlier)

- HUF2 (A karta, C co-parcenary, C's wife member)

- HUF3 (A karta, D co-parcenary, D's wife member)

Using firm/family interlocks, the Rs 300 would be now spread over 3 HUFs and A as an individual in income reporting. This Rs 300 can be distributed among these four entities in various ways. Chartered accountants of P\&S would work out the details of the apportioning to minimize ETR. One way would be to report Rs 50 each as income of each HUF. So each HUF would pay Rs 2.5 as tax on Rs 50, i.e. Rs 7.5 on Rs 150 . A would show his income as Rs 150, on which he would have to pay no tax on the first Rs 25, Rs 2.5 on the next Rs 25, Rs 10 on the next Rs 50 and Rs 15 on the last Rs 50 . So he would pay a total tax of Rs 27.5. All entities together pay only Rs 35 as tax on the same income of Rs 300 . The ETR reduces from $24.2 \%$ (in the absence of HUF) to $11.67 \%$ through judicious use of HUF provisions. If A had three married sons and no daughter, he would be able to form an additional HUF and reduce tax liabilities further. If any of the sons do not get married, then the possibility of forming the additional HUFs reduces. Thus son preference and hetero-normative marriages in every generation, bound by caste and religious rules as per the state's Hindu code, have a very material incentive in the form of the HUF tax provisions in India.

\section{Trends in Effective Direct Taxation of Income: the HUF Compared to Other Categories}

The problem of direct tax mobilization in India in the post-liberalization phase is attributed to high rates of taxation and sources of "inefficiency" traced to the administrative structure of taxation and proliferation of multiple taxes. Thus, in the architecture of tax reforms, the emphasis has been on the "rationalization" of taxes and tax rates $^{4}$ (Rao and Singh 2005). Along with this, the post-liberalization period has seen tax exemptions and tax subsidies being awarded to corporates (Mazumdar 2014; Rao 2015) as a major incentivizing policy tool. This process has generated a large amount 
of opinion without consistent empirical evidence of the fall-outs on effective rates of taxation. One reason for the lack of empirical evidence is the significant change in the process of data dissemination on direct taxes in India. The Central Board of Direct Taxes (CBDT) under the Ministry of Finance has stopped releasing state level data classified by taxation units after 1989-90. It has also stopped disseminating national-level data on actual income assessed and tax collected for various taxation units after 1999-2000. After a long gap and in the face of mounting criticism, in April 2016 the CBDT released partial data for three years (2012 to 2015).Within these constraints, we have compiled taxation data from various volumes of the Statistical Abstract of India and computed effective rates of taxation for the different units of direct income taxation in India. An attempt has also been made to incorporate the plausible analysis of the latest direct tax data released by the CBDT in October 2016, which is being celebrated as a step towards transparency of tax data in India after more than a decade of non availability of disaggregated tax data. But this data suffers from various limitations and hides more than it reveals; an analysis of this is outside the scope of the present discussion. Suffice it to note that the time series from 2001 to 2011 lumps HUF tax data under "other direct taxes." It is only for the years 2012-15 that disaggregated data for the various categories of assessees are available with no distinction between tax payable and actual tax paid. Banerjee and Piketty (2004) used the same data set (called All India Income Tax Statistics) generated by CBDT (which we have used in this paper). They have used it to compute the top shares of income in India from 1922 to 2000 . Their data-set ends in 2000 as the CBDT did not make tax data available since then until very recently. Observing that the share of HUFs is just $5 \%$ of total assessees, Banerjee and Piketty (2004) had merged the HUF assessees with the individual assessees for defining tax units in their analysis. For them the HUF is the same as an individual which is exactly the Indian state's understanding since 1961 . This is why in the contemporary tax structure individual and HUF assessees are treated on par as we have argued so far. Our difference with Banerjee and Piketty (2004) lies in our conceptual critique of not recognizing the HUF as a unique mode of firm-family interlock distinct from individuals which we have illustrated through our discussions so far. It must be noted that the significance of the HUF lies not in how much tax it pays, but in how much wealth it owns on which it does not pay taxes by claiming it as "family income" as illustrated earlier.

Ramanujam a former Chief Commissioner of Income Tax argued that axioms of tax law are based on the assumption that nobody can make a profit out of one's self. The entity of the Hindu Undivided Family (HUF) is an exception to this principle. He noted after the 2005 amendment to the Hindu Code that the HUF is an entity peculiar to the Indian tax law. There is "nothing sham" about it. He succinctly argued that the "government carries out any amount of amendment to the Hindu law without looking into the revenue loss caused by the recognition of the HUF as a separate taxable entity. The HUF may be a boon to the taxpaying Hindu. But it is definitely a bane to government revenues" (Ramanujam 2006). The reporting of taxation data reflects the dichotomy of taxation and corporate governance structures in India. Thus taxation assumes five types of units (individuals, HUFs, firms [sole proprietorships and partnerships], corporates [limited liability companies], and AOP/BOI [Association of Persons/Body of Individuals]) which are reported as separate and distinct without any relationship to each other. On the other hand, our analysis of the institutional structure of corporate governance shows that the institution of the family-owned business group operates through a complex maze of 
interlocked ownership and control across all the five categories. The various reports on tax reforms in the last twenty years also reflect this dichotomy in which the institutional assumptions of corporate tax rationalization completely occlude the purview of the system of self-rationalized tax avoidance offered by the interlocking tax entities. Thus, analyses based on sources like the PROWESS database capture the larger picture of 60$71 \%$ of "firms" (limited liability companies) reporting positive profit before taxes and showing effective taxation rates below $25 \%$ in the last five-year period, and also confirm the observation that larger firms face lower effective tax rates (Rao 2015). While this corroborates our findings discussed below, our point of departure from both Banerjee and Piketty (2004) and Rao (2015) is based on the observation that such studies do not differentiate the type of "firm," the interlocking relationships between "firms," and between firms and HUFs (and AOI/BOIs); hence they do not capture the differential impact of tax policy on different but inter-locked tax entities. Nonetheless, the data reveals some significant features of the Hindu Undivided Family which are incorporated in the discussion that follows.

In Figure 1, we present the annual average effective taxation rates of individuals, HUFs and all other assessees (which consist of different forms of body incorporates or corporate entities-firm, companies, societies and trusts etc.). From 1954-55 to 1998-99, the ETRs of individuals were lowest, the ETRs of corporate entities were highest while the ETR of HUFs was between the two. Also, the ETR of all entities increased between 1973 and 1993. This had to do with the abolition of higher exemptions and lower tax rates to HUFs as compared to individuals, ${ }^{5}$ along with the promulgation of the Monopolies and Restrictive Trades Practices (MRTP) Act in 1971, which recognized the business group as a whole as the unit of organization of capital and put in restrictions on interlocking shareholdings and directorships. Further, the ETRs of HUFs increased significantly in the same period with the abolition of HUF privileges in land and other property holdings (but not corporate holdings which come under the purview of the central government) in Tamil Nadu, Kerala, Andhra Pradesh and Maharashtra. The decline in the ETRs of corporates after the mid-1980s is explained by the dilution of the MRTP Act and its subsequent repeal. The ETRs show a sharp decline in 1998-99 and 1999-2000 after which the CBDT stopped releasing data. The recent data that has been released since 2012-13 to 2014-15 shows a decline in the ETR of individuals. But the steepest decline is recorded by the ETR of HUFs in this period. Figures 1 and 2 together show that, in the period 2012-13 to 2014-15, HUFs have had the lowest ETR since 1956. This decline has been so steep that among the three categories of individuals, HUFs and corporate entities, the HUF has been paying the lowest effective tax in the same period, in which it is growing faster than corporate entities (Table 2.2). 
Figure 1: Annual Average Effective Taxation Rates from 1955 to 2000; 2012-15

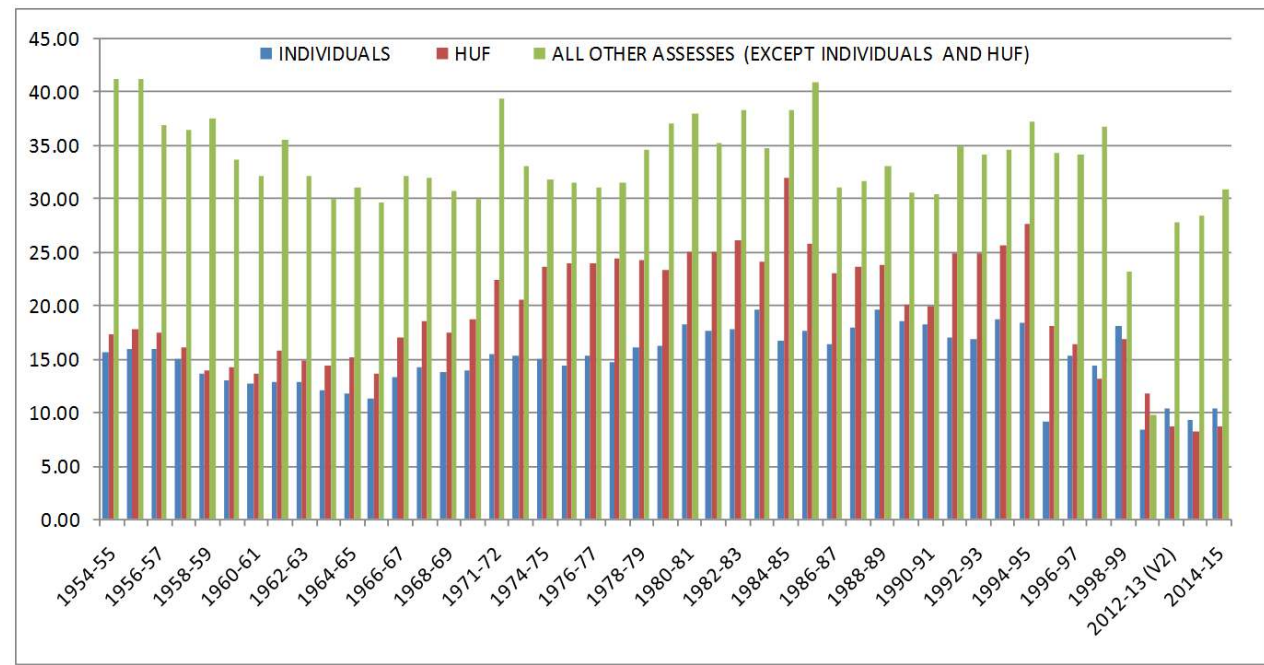

Source: Authors' calculations based on data released by the Central Board of Direct Taxes, Various Years

Note: Data for the years 1970-71, 1973-74 are not available for all assessees. Also, data for registered firms are available from 1956. There is no data available between 2000-01 and 2011-12.

\section{Figure 2: Annual Effective Taxation Rate of HUFs}

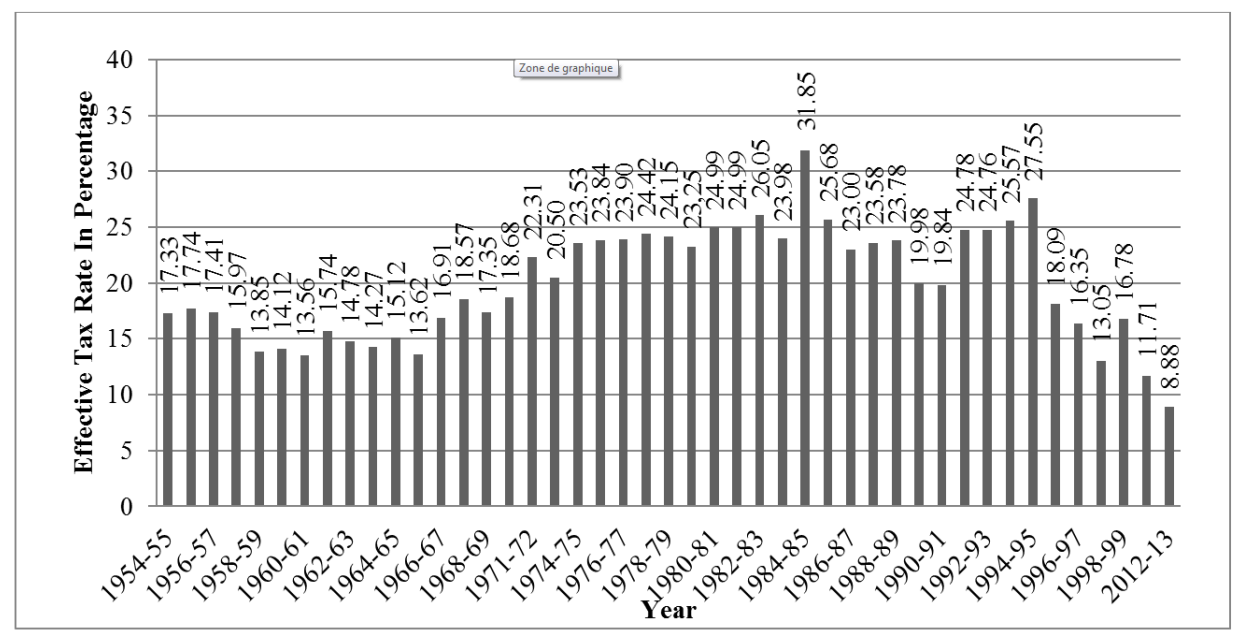

Source: Authors' calculations based on data released by the Central Board of Direct Taxes, Various Years

Table 3.1: Composition of Income of Different Tax Categories: Average Shares (\%) (2012-15)

\begin{tabular}{|l|l|l|l|l|l|}
\hline Category of Income & HUF & Individuals & $\begin{array}{l}\text { Firms and } \\
\text { Companies }\end{array}$ & $\begin{array}{l}\text { AOP/ } \\
\text { BOI }\end{array}$ & Others \\
\hline Salary Income & 0.0 & 52.9 & 0.0 & 0.0 & 0.0 \\
\hline House Property Income & 9.3 & 2.4 & 1.6 & 1.9 & 1.6 \\
\hline
\end{tabular}




\begin{tabular}{|l|l|l|l|l|l|}
\hline $\begin{array}{l}\text { All other Income (business income, short } \\
\text { and long term capital gains, interest etc.) }\end{array}$ & 90.7 & 44.7 & 98.4 & 98.1 & 98.4 \\
\hline Loss Set-Off & 1.08 & 0.97 & 5.04 & 19.5 & 8.22 \\
\hline ETR & 8.28 & 9.69 & 39.06 & 24.92 & 22.23 \\
\hline
\end{tabular}

Source: Authors' calculations based on data released by the Central Board of Direct Taxes, 2016

Figure 3: Effective Income Taxation (\%) Rates by Range of Income (Rs): 2012-2015

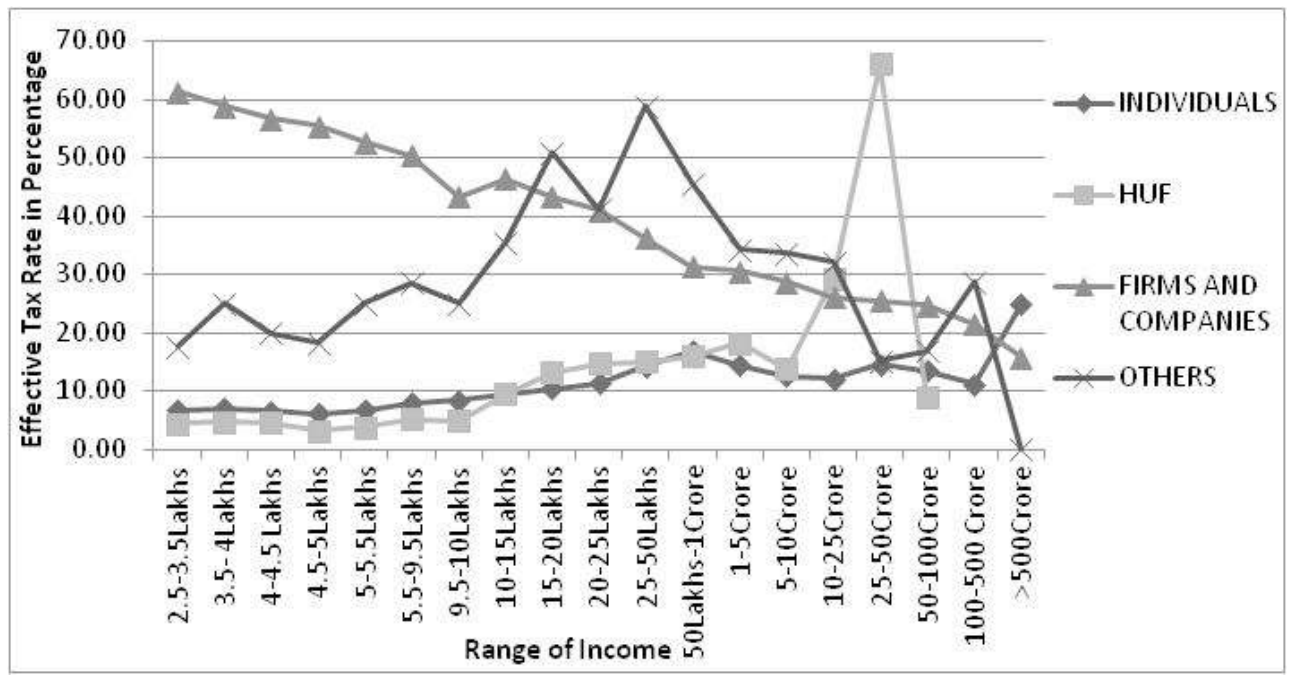

Source: Authors' calculations based on data released by the Central Board of Direct Taxes, 2016 Note: 1 .) 10 lakh = 1 million; 10 million $=1$ crore 2 ). There are only 3 HUFs in the income range of Rs 25-50 crore

51 An analysis of the sources of incomes of for various categories of tax assessees for the period from 2012 to 2015 (the three years for which this data is available) is presented in Table 3.1. More than 90 percent of HUF income accrues from business income, short and long term capital gains and interest income. There is no salary income reported by HUFs. In fact the composition of the HUF income is similar to the income composition of firms, companies and other body incorporates and very different from the composition of individual incomes in which salary income constitutes $52 \%$. Thus the HUF is similar to a corporate entity with the additional characteristic that around $9 \%$ of its income comes from house property while this share is less than $2 \%$ for firms and companies. But, it gets away with exemptions claiming to be a "family" utilizing income for maintenance treated on par with an "individual" tax payer and pays the lowest rates of income tax (Table 3.1).

Figure 3 shows that the effective taxation rates of firms and companies decrease as size of income increases, which is similar to the finding of the study based on the PROWESS database cited earlier, demonstrating the regressive character of corporate taxation in India. For individuals the trend of taxation is progressive but becomes regressive at the top range for incomes above Rs 100 crores. The same trend is evident for the HUF but with two significant features. First, at the bottom end, up to an income below Rs 10 lakhs, the effective rate of taxation of HUFs is consistently less than individual tax assessees. It is only for HUFs which earn an income higher than Rs 10 lakhs, that the effective taxation rates are marginally higher than individual assessees. In the Rs 25 crore to 50 crore range, 
the ETR increases significantly but there are only 4 HUFs with an income above Rs 25 crore (Figure 3). Second, the effective tax paid by the HUF is much less than corporate entities of business even though its income structure is similar to corporate entities as we have shown earlier. Thus the HUF is an inter-locked corporate governance structure whose activities based on income source is typically that of a business incorporate. It is interlocked into the institutional structure of asset, wealth and property holding in India in a maze of interlocked family and business entities spanning all five tax categories which comprise the Hindu family-owned business group. There is no systemic compilation of data by the Indian state on interlocking tax entities and the extent of direct and indirect ownership of economic assets and property by family-owned business groups. The institutional structure of property rights (across all sectors of the economy) in HUFs in India interweaves personal laws, corporate governance structures and tax laws privileging the Hindu male as the asset/property/capital owner. Thus patriarchy and religious discrimination are endogenous to the institutional construction of the structures of corporate governance and taxation that govern both institutions and processes of capital accumulation in India. This institutional structure shows a sturdy continuity in the post-independence period despite ideological shifts in the macroeconomic policy regime.

This institutional structure is embedded in state codification of Hindu family law, corporate governance laws and taxation laws. This unique legal family/firm interlock is not available to Muslims, Christians, Parsis or Jews and hence is a perverse legal privilege for the Hindu business family. The HUF has been and remains the primary unit of organization of family and corporate property, income and wealth reliant on the institutions of majority religion, caste and patriarchy.

\section{BIBLIOGRAPHY}

Agnes, Flavia. 2011. Family Law and Constitutional Claims. Vol. 1, Family Law. New Delhi: Oxford University Press.

Agnes, Flavia. 1999. Law and Gender Inequality: The Politics of Women's Rights in India. New Delhi: Oxford University Press.

Ayers, C. W. 1936. Income Tax Enquiry Report. New Delhi: Government of India Press.

Bagchi, Amiya K. 1972. Private Investment in India 1900-1939. Cambridge: Cambridge University Press.

Bandyopadhyay, Sankhanath. 2012. "Tax Exemptions in India." Budget Track 8(3): 20-23. Centre for Budget and Governance Accountability. Retrieved March 15, 2017 (http:// www.cbgaindia.org/budget-tracks/vol-8-track-3-2012/).

Banerjee, Abhijit and Thomas Piketty. 2004. “Top Indian Incomes 1922-2000." Centre for Economic Policy Research, Discussion Paper 4632. Retrieved March 15, 2017 (http:// piketty.pse.ens.fr/fichiers/public/BanerjeePiketty2004.pdf). 
Birla, Ritu. 2008. Stages of Capital: Law, Culture and Market Governance in Late Colonial India. Durham: Duke University Press.

Bhoothalingam, S. 1968. Final Report on Rationalisation and Simplification of the Tax Structure. New Delhi: Government of India Press.

Damodaran, Harish. 2008. India's New Capitalists: Caste, Business and Industry in a Modern Nation. Basingstoke: Palgrave Macmillian.

Das Gupta, Chirashree. 2016. State and Capital in Independent India: Institutions and Accumulation. Delhi: Cambridge University Press.

Das Gupta, Chirashree. 2013. "The Tenacity of the Hindu Undivided Family: Gender, Religion and Tax Concessions." Economic and Political Weekly 48(40): 73-5.

Das Gupta, Chirashree. 2010. "Globalisation, Corporate Legal Liability and Big Business Houses in India." Cambridge Journal of Economics 34(5): 895-913.

De Beule, Filip and K. Narayanan 2016. "Globalization of Indian Industries: How to Move Forward?" Pp 1-15 in Globalization of Indian Industries: Productivity, Exports and Investment, edited by F. De Beule and K. Narayanan. Singapore: Springer.

Dewan, Ritu. 2009. “Indian Taxation Systems and Policies: A Gendered Critique.” Pp. 117-138 in Macro Economics and Gender, edited by R. Dewan and K. Prabhu Seeta. New Delhi: Zubaan Books. Govinda Rao, M. and Nirvikar Singh. 2005. Political Economy of Federalism in India. New Delhi: Oxford University Press.

Gulzar, M. A. and Z. J. Wang. 2010. “Corporate Governance and Non-Listed Family Owned Businesses: An Evidence from Pakistan." International Journal of Innovation, Management and Technology 1(2): 124-129.

Hazari, Rabindra K. 1967. Industrial Planning and Licensing Policy: Final Report. Planning Commission. New Delhi: Government of India.

Kelkar, Govind. 2014. “The Fog of Entitlement: Women's Inheritance and Land Rights.” Economic and Political Weekly 49(33): 51-58.

Markovits, Claude. 1985. Indian Business and Nationalist Politics 1931-39: The Indigenous Capitalist: Class and the Rise of the Congress Party. Cambridge: Cambridge University Press.

Marx, Karl. 1887. Capital: A Critique of Political Economy. Vol. 1. Retrieved December 31, 2016 ( https://www.marxist.org/archive/marx/works/download/pdf/Capital-Volume1.pdf).

Matthai, John. 1955. Report of the Taxation Enquiry Commission (1953-54). Vol. 2. Ministry of Finance (Dept. of Economic Affairs). New Delhi: Government of India Press.

Mazumdar, Surajit. 2014. “Union Budget 2014-15 and the Myth of UPA's 'Populism.” Vikalp, March 3. Retrieved February 2, 2016 (http://www.vikalp.ind.in/2014/03/union-budget-2014-15and-myth-of-upas.html).

Mazumdar, Surajit. 2006. "Business Groups and Concentration in the Private Corporate Sector in India." PhD dissertation, Centre for Economic Studies and Planning, Jawaharlal Nehru University, New Delhi

Naz, Raveena. 2016. "The Conflict between Corporate Governance and Corporate Social Responsibility in India." Presented at Fourth LASSNET Conference, December 12, New Delhi. Newbigin, Eleanor. 2013. The Hindu Family and the Emergence of Modern India: Law, Citizenship and Community. New York: Cambridge University Press. 
Owens, Raymond. 1971. “Industrialization and the Indian joint Family.” Ethnology 10(2): 223-50.

Parashar, Archana. 1992. Women and Family Law Reform in India: Uniform Civil Code and Gender Equality. New Delhi: Sage Publications.

Raj, K. N. 1972. Report of the Committee on Taxation of Agricultural Wealth and Income. Ministry of Finance. New Delhi: Government of India

Ramanujam, T. C. A. 2006. “HUF: Bane or Boon?” The Hindu Business Line, August 12. Retrieved December 31, 2016 (http://www.thehindubusinessline.com/todays-paper/tp-opinion/huf-baneor-boon/article1742734.ece).

Rao, Kavita. 2015. “Corporate Taxes and Exemptions: What Does the Proposed Agenda Mean?" Economic and Political Weekly 50(12): 27-29.

Sachdeva, Updesh S. 1987. Hindu Undivided Family: Law Judiciary and Bankers. New Delhi: UDH Publishers and Distributors.

Sarkar, Jayati and Subrata Sarkar. 2012. Corporate Governance in India. New Delhi: Sage Publications.

Schaffer, Mark E. and Gerard Turley. 2001. "Effective Versus Statutory Taxation: Measuring Effective Tax Administration in Transition Economies." European Bank of Reconstruction and Development, Working Paper 62. Retrieved March 15, 2017 (http://www.ebrd.com/downloads/ research/economics/workingpapers/wp0062.pdf).

Singh, Kirti. 2005. "Amendments to the Hindu Succession Act-Are They Enough to Bring about Gender Equality?" Combat Law 3(5): 36-37.

Singer, Milton. 1968. "The Indian Joint Family in Modern Industry." Pp 423-52 in Structure and Change in the Indian Society, edited by M. Singer and B. S. Cohn. Chicago: Aldine Publication Company.

Tripathi, Dwijendra and Makrand Mehta. 1990. Business Houses in Western India: A Study in Entrepreneurial Response, 1850-1956. New Delhi: Manohar Publications.

Tyabji, Nasir. 2000. Industrialisation and Innovation: The Indian Experience. New Delhi: Sage Publications.

Tyagi, Mahahvir. 1960. Report of the Direct Taxes Administration Enquiry Committee (1958-59). New Delhi: Government of India Press.

Varadachari, S. 1949. Report of the Income-Tax Investigation Commission. New Delhi: Government of India Press.

Wanchoo, Kailash N. 1971. Final Report of the Direct Taxes Enquiry Committee. New Delhi: Government of India Press.

Washbrook, David. 1981. "Law, State and Agrarian Society in Colonial India." Journal of Modern Asian Studies 15(3): 649-721.

\section{NOTES}

1. See Das Gupta (2016) for detailed case studies.

2. In their reports, the Vardachari Commission (1949) and the Matthai Commission (1953) justified exemption of HUF income from income tax and suggested twice and thrice the exemption limit to individuals. Both the committees were of the opinion that the sentiments 
involved in remaining undivided should be given consideration and that enough concessions should be made for those who otherwise want to remain undivided but, for the purpose of lowering taxation, go for partition. Their recommendations were given effect through the subsequent Finance Acts.

3. The Mahavir Tyagi Committee (1958) did not mention the HUF as a tool for tax evasion while it recognized trust and cooperative society to be so. The Bhoothalingam committee (1967) did mention the HUF as a tool for tax evasion, but regarded administrative burden as the reason not to intervene in the provision. It was only the Wanchoo (1971) and K. N. Raj (1972) committees that pointed to the HUF as a tax evading entity and suggested withdrawal of tax exemptions.

4. See Academic Foundation 2003.

5. The statutory tax rate for the HUF has been the same as that of individuals since the intervention of the Wanchoo Committee and the K. N. Raj Committee, because of which the lower tax rates for HUFs were raised to the level of the individual income-tax payer and the higher exemption limit was done away with in the 1970s.

\section{ABSTRACTS}

Social science has had a very limited engagement with the socio-legal entity of the Hindu Undivided Family (HUF). In corporate and personal law-the two spaces it inhabits-it has been largely regarded as separate and distinct entity from "modern" tax and corporate governance entities like individuals and body incorporates. It is often referred to as an archaic remnant associated with feudal structures of land and property holdings. Its implications on capital accumulation in the "modern" structures of corporate governance and tax structures have not been studied at all. This paper is an attempt to arrive at a comprehensive delineation of the role of the HUF in the corporate governance and taxation regime in independent India.

\section{INDEX}

Keywords: HUF, family firm, business group, taxation, corporate governance, capital accumulation

\section{AUTHORS}

\section{CHIRASHREE DAS GUPTA}

Associate Professor, Centre for the Study of Law and Governance, Jawaharlal Nehru University, New Delhi

\section{MOHIT GUPTA}

MPhil candidate, Centre for the Study of Law and Governance, Jawaharlal Nehru University, New Delhi 